\title{
A TRIANONI ORSZÁGHATÁROK KIALAKÍTÁSA
}

Establishing new borders by the Treaty of Trianon

\section{SUBA JÁNOS}

Hadtörténeti Intézet és Múzeum, Hadtörténeti Térképtár

suba.janos@mail.militaria.hu

\section{ABSTRACT}

The operation of the committees whose task was to set the border can be divided into two phases. One of them was the ,delimitation', which means to establish and work on site the political borderline described in the peace treaty. The other was the ,demarcation', which was setting the border as a purely technical process. Points marked on the map had to be marked with real points on the spot, plus perpetuated by different border signs. After that the borderline could be measured, which actually means mapping the borderline and its surroundings in a particular lane. The activity and moving of the committees extended only to a narrow lane on both sides of the Trianon line, which showed that they were only prepared for local adjustment.

The borderlines were divided into sections in order to share the setting, measuring and financial burden. The setting of the borderline was proceeded only slowly and in more phases in most of the sections as the committee was voting. Nevertheless, by the end of 1922 it was completed, except some minor parts. After that each border point was perpetuated with different border signs according to their importance. The mapping of the borderline was executed in a given lane. After signing the border documents the committees were broken up as their task was finally carried out. Nevertheless, in some places there were small rectifications, partly by the decision of the committees, partly due to referenda, is one case the League of Nations expressed the last word.

Keywords: Trianon Peace Treaty, state border, Boundary Committee, delimitation, demarcation, metes and bounds

„...Kitervezni az új határokat, könnyü. Csakhogy minden határ más államnak is a határa.” (KriszTiCs S. 1927)

\section{BEVEZETÉS}

A történelmi Magyar Királyság „ezeréves” határai az I. világháborút Magyarország szempontjából lezáró „trianoni” békeszerződés következtében megváltoztak, teljesen új határvonalakat kellett meghúzni (1. ábra). Ennek kijelölése, a határ pontjainak kitüzése nemcsak fájdalmas, de nehéz feladatot is jelentett. Az írás a következőkben ezen - kis módosításokkal 
immár száz éve fennálló - határok meghúzásának, kitűzésének az alapvetéseit és egyes érdekességeit ismerteti. A békeszerződést a felek 1920. június 4-én Versailles-ban, az ún. Nagy-Trianon kastélyban írták alá, ezért ismert mindmáig „trianoni” néven.

\section{A HATÁROK MEGÁLLAPÍTÁSÁNAK JOGI HÁTTERE}

A határ fogalmát a földrajzban sokan és sokféleképpen értelmezik (ezt részletesen elemzi pl. Tóтн J. 2011). A határ lényegében a társadalmi tér horizontális felosztásának egy mesterséges eszköze, leggyakrabban egy elválasztó vonal, ami ráadásul állandóan változik. Az államhatár azonban több ennél, hiszen egy jogi fogalom is, ezért a továbbiakban a határ fogalmát ebben az értelemben használjuk. Amikor két ország meghatározza, rögzíti a közöttük lévő határt, akkor egyrészt szilárd és végleges megoldásra törekszik, másrészt jogilag kölcsönösen kötelezettséget is vállal annak állandósítására. A határ megállapítása mindig politikai döntés eredménye, jogi eszközökkel kifejezve (SuBA J. 2002, 2004, 2008).

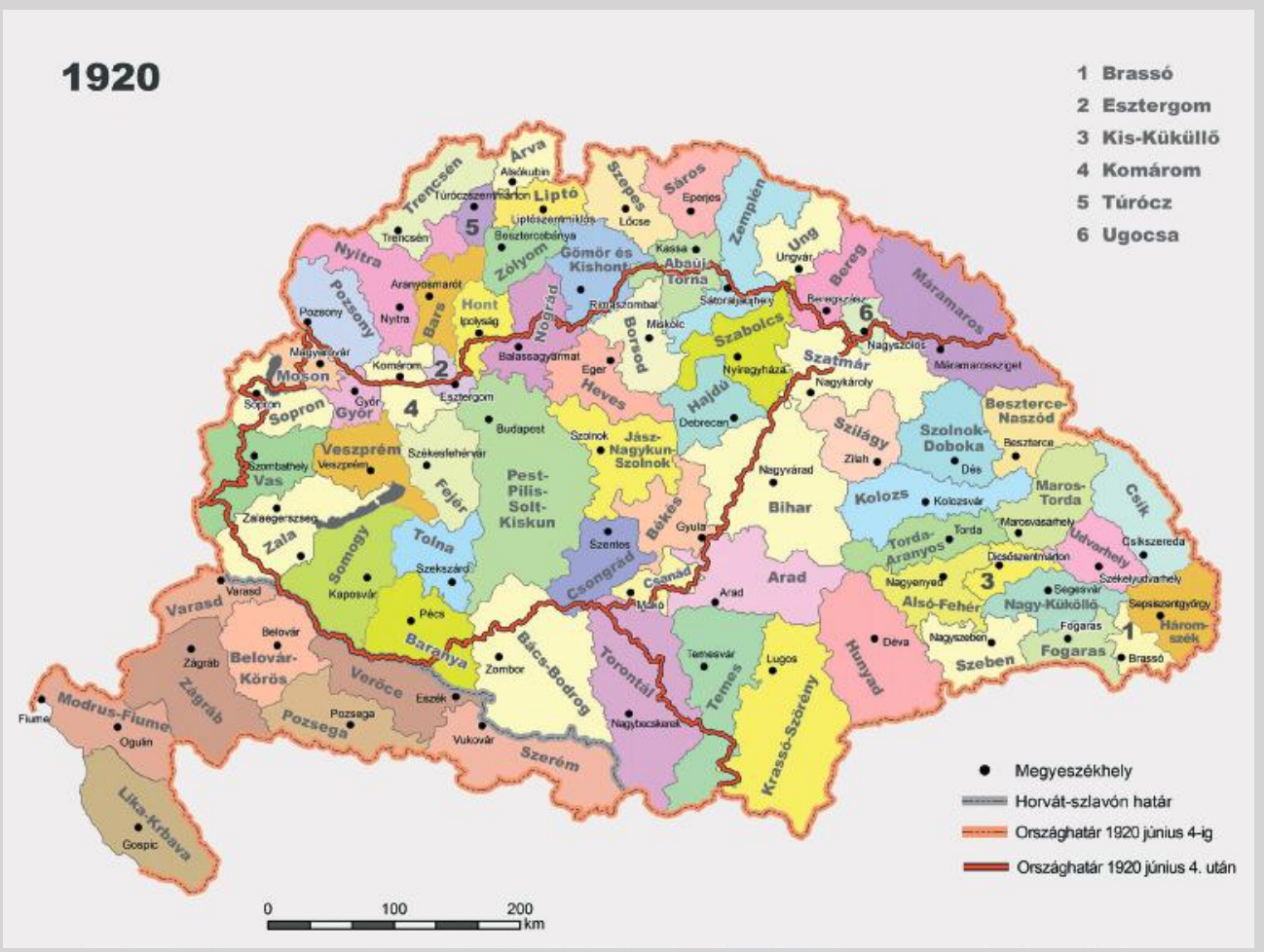

1. ábra. Magyarország határai és megyéi a trianoni békeszerződés elött és után (szerk. CsüLLÖG G.) 
A határok megállapításának első szakasza rendszerint az államhatár megvonása (delimitáció), amelynek fő eleme az adott terület politikai hovatartozásának szerződéseken alapuló eldöntése. Természetesen meghatározzák a határvonal irányát is, az adatokat pedig a szerződés mellékletét képező térképen is ábrázolják. A második lépés az államhatárok térbeni megjelenítése (demarkáció), azaz a határpontok, határvonalak terepen való kitűzése az adott térségben. Ezt a munkát rendszerint egy - az államok által létrehozott - kétoldalú (némely esetben többoldalú) határmegállapító bizottság hajtja végre. A kitűzést követi a határ messziről láthatóvá tétele, aminek érdekében a kitűzött határvonalat különböző határjelekkel jelölik meg. Természetesen kölcsönös megállapodás alapján sor kerülhet a korábban elvégzett határjelölés felülvizsgálatára (redemarkáció) is, ami nyilvánvalóan új határjelzések elhelyezésével, a régiek megváltoztatásával, esetleg kicserélésével jár.

A fentieket összefoglalva tehát elmondható, hogy a határok kitűzésének politikai és technikai kérdései külön-külön kérdéskört alkotnak. Az új „trianoni” határokat megállapító bizottságok müködése is ennek megfelelően két szakaszra oszlott: első volt a békeszerződésben leírt politikai határvonal megállapítása és térképi kijelölése, a második pedig a határkitűzés technikai müvelete, azaz a térképen bejelölt pontok megjelenítése a terepen és különböző határjelekkel való állandósításuk.

A trianoni békeszerződésben több cikk (vagy ahogy akkoriban nevezték, cikkely) is foglalkozott Magyarország új határvonalával. A 27. cikk igen nagy általánosságban írja le a határvonal menetét, a leendő határt különböző szakaszokra osztva tárgyalja, és azokat a 28. cikkben egy igen kis (1:1 000 000) méretarányú térképen ábrázolja (2.ábra), megjegyezve, hogy a pontos határ „a helyszínen megállapítandó vonal”. A határvonal részletes megállapítását a 29 . cikk a bizottságokra bízza, amelyek a Szövetséges és Társult Hatalmak, valamint az érdekelt államok képviselöiből állnak (ennek részleteit más cikkek írták elö). A 30. cikk a vízfolyásokkal megjelölt határvonalat aszerint határozza meg, hogy hajózható, vagy nem hajózható vízfolyásról van-e szó. A 34. cikk kimondja, hogy a határköveket egymástól

2. ábra. A trianoni békeszerződés 28. cikkéhez csatolt 1:1 000000 méretarányú térkép részlete a Rába és a Mura közötti szakaszon kijelölt új határvonallal (forrás: Hadtörténeti Térképtár B. XV. c. 321.)

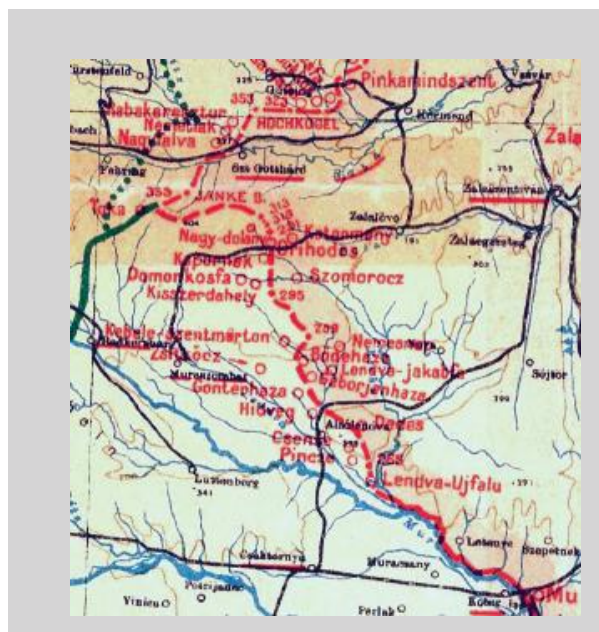


„látótávolságnyira” kell elhelyezni. Emiatt kedvezőtlen terepviszonyok esetén a határkövek meglehetősen sürűn követték egymást, ami persze jelentős költségekkel is járt.

A szerződést gyakorlati kérdésekkel foglalkozó utasítások is kiegészítették, amelyek pl. általános szinten szabályozták a határmegállapító bizottságok szervezetét, jogkörét, működésének elveit, az utasítás műszaki részében pedig a határkitűző munkálatok menetét, munkamódszerét és elkészítendő okmányait. A határvonal tényleges, részleges megjelölésére, kitűzésére, térképezésére, a határokmányok elkészítésére a Szövetséges és Társult Hatalmak nemzetközi határmegállapító bizottságokat hoztak létre, amelyek 1921-1925 között végezték el a munkát. Az új határok kijelölése nyilvánvalóan nem lehetett problémamentes. Emiatt egy évvel a trianoni szerződés aláirását követően, 1921. június 3-án a felmerülő problémák megoldására egy újabb utasítás született „Pótutasítások a magyarországi határmegállapitó bizottságok részére” címmel, amely hangsúlyozta, hogy „...Elvileg a határt a helyszinen kell megvonni, úgy, amint a békeszerzödés megállapította. Semmi szín alatt nem szabad... a határmódosításoknak olyan természetüeknek lenniük, hogy lényegében kérdésessé tegyék a szerződésben leírt vonalat". A határmegállapító bizottságok feladata volt egyrészt az államhatárok konkrét megvonása (ez volt a politikai rész, tárgyalásokkal, javaslatok és ellenjavaslatok mérlegelésével), másrészt a műszaki-geodéziai feladatok megoldása (határvonal kijelölése, pontok kitűzése, állandósítása, határkövek, felállítása stb.).

A politikai háttér egyik fontos, a magyar fél számára némi reményt nyújtó eleme volt az ún. Millerand-levél, amit AleXandre Millerand akkori francia miniszterelnök írt, és a békeszerződés mellékletének számított. Ez tulajdonképpen némi rugalmasságot helyezett kilátásba a trianoni határokat illetően: „...A helyszínen megejtett vizsgálat esetleg szükségessé fogja tenni, hogy egyes helyeken a szerzödésben megállapitott határt áthelyezzék... ha a határmegállapitó bizottságok... úgy vélik, hogy a szerzödés intézkedései... valahol igazságtalanok,... módjukban lesz erröl jelentést tenni a Nemzetek Szövetsége Tanácsának. Ebben az esetben a Szövetséges és Társult Hatalmak hozzájárulnak, hogy ha az egyik érdekelt fél kéri, a Szövetségek Tanácsa felajánlhassa jó szolgálatait abból a célból, hogy az eredeti határt ugyanazon feltételek mellett, békés úton megváltoztassa ott, ahol ennek megváltoztatását valamelyik bizottság kívánatosnak mondja”. Sajnos a későbbiekben a konkrét határmegállapítások során a bizottságok lényegében figyelmen kívül hagyták, vagy a maguk szájízének megfelelően értelmezték ezt az okmányt.

\section{A HATÁRMEGÁLLAPÍTÓ BIZOTTSÁGOK MŰKÖDÉSE}

A határmegállapító bizottságok az új szomszéd országok menti, tehát magyar-csehszlovák, magyar-román, magyar-szerb-horvát-szlovén (a továbbiakban: jugoszláv) és 
magyar-osztrák határok kijelölését végezték el. A munkát a határvonal általános tanulmányozásával kezdték. Ennek az volt a célja, hogy megállapítsák azokat a határrészeket, amelyekre nézve pontosan lehetett alkalmazni a békeszerződés rendelkezéseit, valamint azokat a határszakaszokat, amelyek vitára adtak okot. Megállapítható, hogy a bizottságok lényegében szinte minden esetben - Magyarország rovására - az utódállamok általános és helyi gazdasági érdekeit tartották szem előtt. Abból a felfogásból indultak ki, hogy Magyarország a jelen helyzetében is életképes állam, emiatt a határvonal tanulmányozása során például a nemzetiségi viszonyok elbírálását másodrendü kérdéssé tették. Csak kisebb, lényegtelen kérdésekben adtak helyt a magyar álláspontnak, lényeges kérdésekben a bizottságok tagjai a franciák által támogatott másik fél javára döntöttek. Az említett Millerand-levél - amelyhez a magyar kormány nagy reményeket füzött - a gyakorlatban csekély értékűnek bizonyult, sőt általában a magyar fél hátrányára értelmezték, és a bizottságok munkájának szabadságát is a magyar fél kárára korlátozták. Például a magyar-jugoszláv bizottság szerb biztosa kereken kijelentette, hogy kormánya a kísérőlevelet nem ismeri el, és nem vesz részt olyan tárgyalásban, amely a trianoni vonaltól eltérő határra vonatkozna (SuBA J. 1999). A bizottság többi tagja is kizártnak tartotta, hogy egy-egy nagyobb községet vagy területet a magyaroknak ítéljenek. Lényegében hasonló volt a helyzet a többi bizottság esetében is.

A határmegállapító bizottságok müködésüket arra az elvre alapozták, amelynek értelmében egyik fél sem támadhatja meg különféle javaslatokkal a béke alapjait (basé du traité). A gond csak az volt, hogy a béke alapjai értelmezésében részben eltérö vélemények és felfogások alakultak ki az egyes bizottságokban. Így pl. a magyar-jugoszláv bizottság a stratégiai pontokat, nagyobb településeket, városokat, vasúti fővonalakat, vasúti csomópontokat vagy a katonai jelentőségü terepszakaszokat tekintette a béke bázisául. A magyar-csehszlovák bizottság a trianoni vonalhoz ragaszkodott (SuBA J. 1997a), amelytől a bizottság szerint eltérni legfeljebb gazdasági okokból lehet egyes helyeken. A magyar-román bizottság a román fél érdekei alapján konkretizálta a béke alapját, ami nem volt más, mint a románok számára stratégiai fontosságú Nagyszalonta-NagyváradSzatmárnémeti vasútvonal (SuBA J. 2000a), és a románok egyetlen települést sem voltak hajlandók visszaadni. Lényegében a bizottságok csak olyan javaslatokat fogadtak el és tettek meg tárgyalási alapnak, amelyek megfeleltek az ő (általában az új országokat támogató) felfogásuknak a béke alapjairól, minden javaslatot ebből a szempontból mérlegeltek. Különösen állt ez a magyar-román bizottság müködésére. A tárgyalások helyszíni szemlékkel is párosultak, de azok során az etnikai helyzetet nem vették figyelembe, csak arra szolgáltak, hogy a bizottságok közvetlen tapasztalatokat szerezzenek egyes határszakaszok gazdasági helyzetéről. Bár ez utóbbit sem vették mindig figyelembe, pl. az északnyugati hármashatárt a Batthyány-Strattmann családi birtok kellős közepén jelölték 
ki, a birtokot három állam között osztottak fel: az uradalom 958 hektárnyi területéből 495 hektárt egy majorral Csehszlovákiához, a köpcsényi hercegi kastélyt 3 hektárral Ausztriához csatolták, míg 460 ha Magyarország része maradt. A helyszíni szemle hiába javasolta, hogy a hármashatárpont a Batthyány-Strattmann birtok széleire essék, a határmegállapító bizottság hajthatatlan volt (SUBA J. 1997b; 3. ábra).

Számos tanulmány, emlékirat, feljegyzés tanúsítja, hogy a szemlék lebonyolításakor a bizottsági tagok mindenütt megtapasztalhatták a lakosság érzelmeit, de ez a döntéseiket lényegében nem befolyásolta. Nem jártak eredménnyel az érdekelt államok közötti közvetlen tárgyalások sem. A magyar fél semmilyen érdemleges engedményt nem tudott elérni, sőt a bátorított új államok még újabb és újabb területi követelésekkel álltak elő. Ezt elősegítette, hogy a bizottságok az említett Millerand-levélnek a magyarok számára kedvezőnek értelmezhető kitételeit nemcsak hogy nem vették figyelembe, hanem a levélnek olyan értelmezést adtak, ami szerint az új államalakulatok ugyanúgy követelhetnek a még magyar területekböl, mint a magyarok a „megszállt területekből”. Azaz a Szövetséges és Társult Hatalmak képviselői a nekik kényelmesebb kisantant-felfogást tették magukévá, vagyis semmiféle kedvezményt nem adtak a magyaroknak.

Összességében a bizottságok tevékenysége és mozgása a trianoni vonal mindkét oldalán csak egy szűk sávra terjedt ki, ahol a magyarok számára kedvező határkiigazítást csak esetleges helyi gazdasági érdekek alapján találtak indokoltnak, és a bizottságok által képviselt elvek és utasítások szinte teljesen leszükítették és korlátozták a magyar igényeket és törekvéseket. Így komoly határkiigazítás az utódállamok ellenkezése és a határmódosításokat jóváhagyó Nemzetek Szövetségének (ez a mai ENSZ elődje volt, röviden Népszövetségnek szokás nevezni) tehetetlensége miatt nem történt.

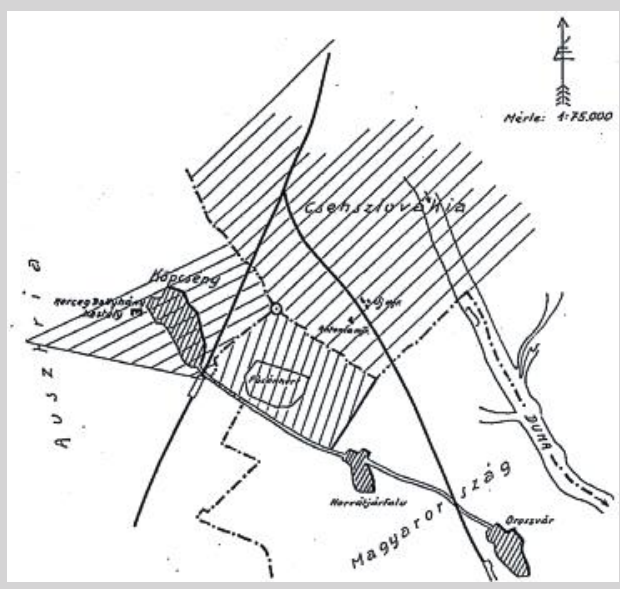

A határmegállapító bizottságok gyakorlati tevékenységének eredményeként Magyarország „nyeresége” kerekítve 46450 ha volt, az alábbi megoszlásban: a csehszlovák határon 5763 ha; a román határon 9752 ha; a jugoszláv határon 19566 ha; végül az osztrák határon 11369 ha.

3. ábra. Az északnyugati hármashatár kijelölése során Köpcsénynél a BatthyányStrattmann család birtokát három ország között osztották fel (forrás: a Magyar Nemzeti Levéltár határmegállapitási anyaga) 


\section{A MÜSZAKI MUNKÁLATOK}

Mint fentebb már erről szó esett, az új határok megállapításának második szakasza az államhatárok térbeni megjelenítése, azaz az újonnan megállapított határvonal kitűzése, szükség esetén határnyiladékok kialakítása, a határvonal határjelekkel való állandó megjelölése, számszerü felmérése, térképezése és a határleírási jegyzőkönyvek elkészítése volt (SuBA J. 2008). Erre a célra az érdekelt államok mindegyike mérnököket bocsátott a bizottságok rendelkezésére. Mivel a munkálatok műszaki vonatkozású részeinek nem volt egyértelmű szabályozása, ezért minden egyes bizottság külön műszaki végrehajtási utasítást dolgozott ki, amelyek alapvetően az 1904. évi magyar kataszteri felmérési utasításnak a határ megállapítására vonatkozó rendelkezésein alapultak.

A határvonalakat a kitűzés, a felmérés és az anyagi teherviselés megosztása érdekében szakaszokra osztották fel: a csehszlovák határvonalat 27 szakaszra (ezeket római számokkal jelölték); a román határvonalat 11, a jugoszlávot 6, az osztrákot 3 szakaszra osztották fel (ezeket az abc nagybetüivel jelölték). Egyes szakaszokon az új szomszédos országok mérnökei közösen dolgoztak, más határvonalakon felosztották egymás között a határvonal műszaki munkálatait. A határvonal kitűzéséhez a határmegállapító bizottság az általuk kijelölt határvonalról részletes leírást adott a bizottság müszaki csoportjának, amelyek kézhezvétele után a terepen fakarókkal ideiglenesen tűzték ki a határvonalat. Az ideiglenes kijelölés után a müszaki bizottság tagjai bejárták a határszakaszt és ellenőrizték, hogy az valóban megfelel-e a megállapított határvonalnak és a kiadott müszaki utasításoknak. A vizsgálat során felmerült észrevételekről jegyzőkönyvet vettek fel, amit beterjesztették a határmegállapító bizottsághoz. Az új határvonal kijelölése a legtöbb szakaszon csak lassan és részletekben történt meg, ahogy azokat a bizottságok jóváhagyóan megszavazták, de egyes kisebb részek kivételével egészében 1922 végére lezárult.

$\mathrm{Az}$ ideiglenes határjelek kitűzésének jóváhagyása esetén következhetett a határvonal állandósítása határjelekkel. Ez lehetett többféle határkő, egyszerübb (4. ábra) és hármashatárkő (5. ábra), vagy faoszlop, esetleg határdomb. A négy határ mentén azonban ez sem volt egységes. Pl. a román határon az ideiglenes mentén, Ólmod településnél (forrás: https:// mapio.net/pic/p-11092399/)

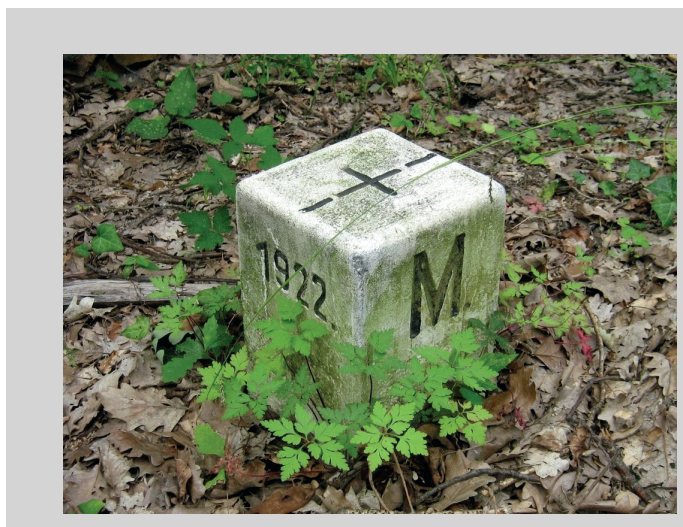




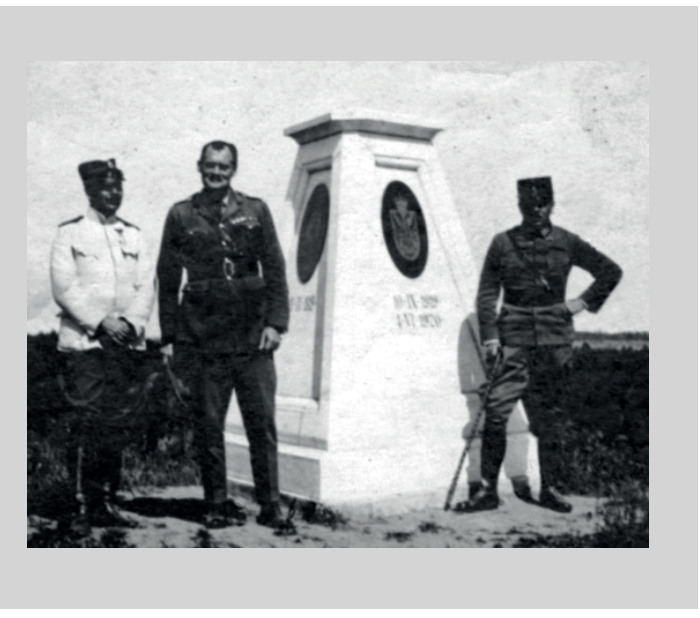

5. ábra. Román-jugoszláv-magyar hármashatárkö az 1920-as évek elején (forrás: a Magyar Nemzeti Levéltár határmegállapitási anyaga)

határkarók helyére vasbeton határköveket helyeztek el, úgy, hogy minden 300-500 méterre egy-egy főhatárkövet tettek le, s a közöttük húzódó határrész kisebb töréseit úgynevezett mellékhatárkövekkel állandósították. A mocsaras határrészeken határkövek helyett táblával ellátott, többnyire tölgyfából készült ún. fapilótákat helyeztek le, amelyeket a tartósítás érdekében vegyileg impregnáltak. Az osztrákok a határvonal minden törését kövekkel akarták állandósítani, ami miatt sok helyen egymástól néhány méterre kellett volna a köveket felállítani, holott a müszaki utasítás 200 méteres távolságot írt elő. A magyar fél a 100 méteres távolságot javasolta. Végül is a fököveket egy kilométeres távolságra állították fel, száz méterenként pedig közönséges határköveket helyeztek le, amelyeket folyamatosan számoztak. Azokon a határszakaszokon, ahol a magyarok dolgoztak, műköveket, az osztrákoknak kiutalt szakaszokon termésköveket használtak (SUBA J. 1997b). A jugoszláv határszakaszon a határköveket 300-400 méterenként helyezték el, a közük lévő töréspontokat, hajlatokat határdombbal jelölték (SubA J. 1999). A csehszlovák határszakaszon a határvonal kijelölése után a végleges határt betü- és számjelekkel ellátott határkövekkel jelölték meg (SUBA J. 1997a).

\section{ÉRDEKESSÉGEK, FURCSASÁGOKATRIANONIHATÁROKMEGHÚZÁSATERÉN}

A „nyelvhatár” elvileg alapja lehetett volna egy új határ meghúzásának, persze nem mindenhol, hiszen számos helyen olyan vegyesen éltek a különböző nemzetek, hogy ilyen határokat nem is lehetett volna kijelölni. Mégis összességében a trianoni békeszerződés egyik legnagyobb igazságtalanságának mondható, hogy az új határvonalat mindenütt a magyar nyelvhatáron belül, sokszor annál akár 100 kilométernél is beljebb vonták meg. Ezzel is magyarázható, hogy a magyarság több mint egyharmada került új államokba. Egy-egy nem magyar község kedvéért néha 10-20 magyar községet is át kellett adni! Például Ausztriához a Sopron megyei Locsmánd és Répcemiske német községek megszerzése érdekében 10 horvát és 2 magyar, míg a Vas megyei Rohonc és Városhodász német községek átadása kedvéért 3 magyar (Felsőőr, Alsóőr, Örsziget) és 14 horvát községet csatoltak el. 
A határok megállapításakor nagyon fontos szerepet töltöttek be a vasútvonalak mind gazdasági, mind katonai értelemben, ezek megszerzését az utódállamok stratégiai fontosságú kérdésnek tekintették. A vasúthálózat 42\%-a maradt meg. A nagy vasúti gócpontokat (Pozsony, Kassa, Sátoraljaújhely, Nagyvárad, Arad, Temesvár, Szabadka) mind elcsatolták, de ezeken kívül további sok kisebb, de azért a vasúti összeköttetés szempontjából fontos gócpontot vettek el, ilyen települések voltak például Párkánynána. Losonc, Fülek, Pelsőc, Csap, Bátyu, Királyháza, Szatmár, Nagykároly, Érmihályfalva, Biharpüspöki, Horgos (6. ábra). A határok megállapításakor 220 községnek a területét kettészelték, mégpedig 50 községét a román, 22 községét az osztrák, 76 községét a cseh és 70 községét a jugoszláv határon. 1011 egyéni birtokosnak

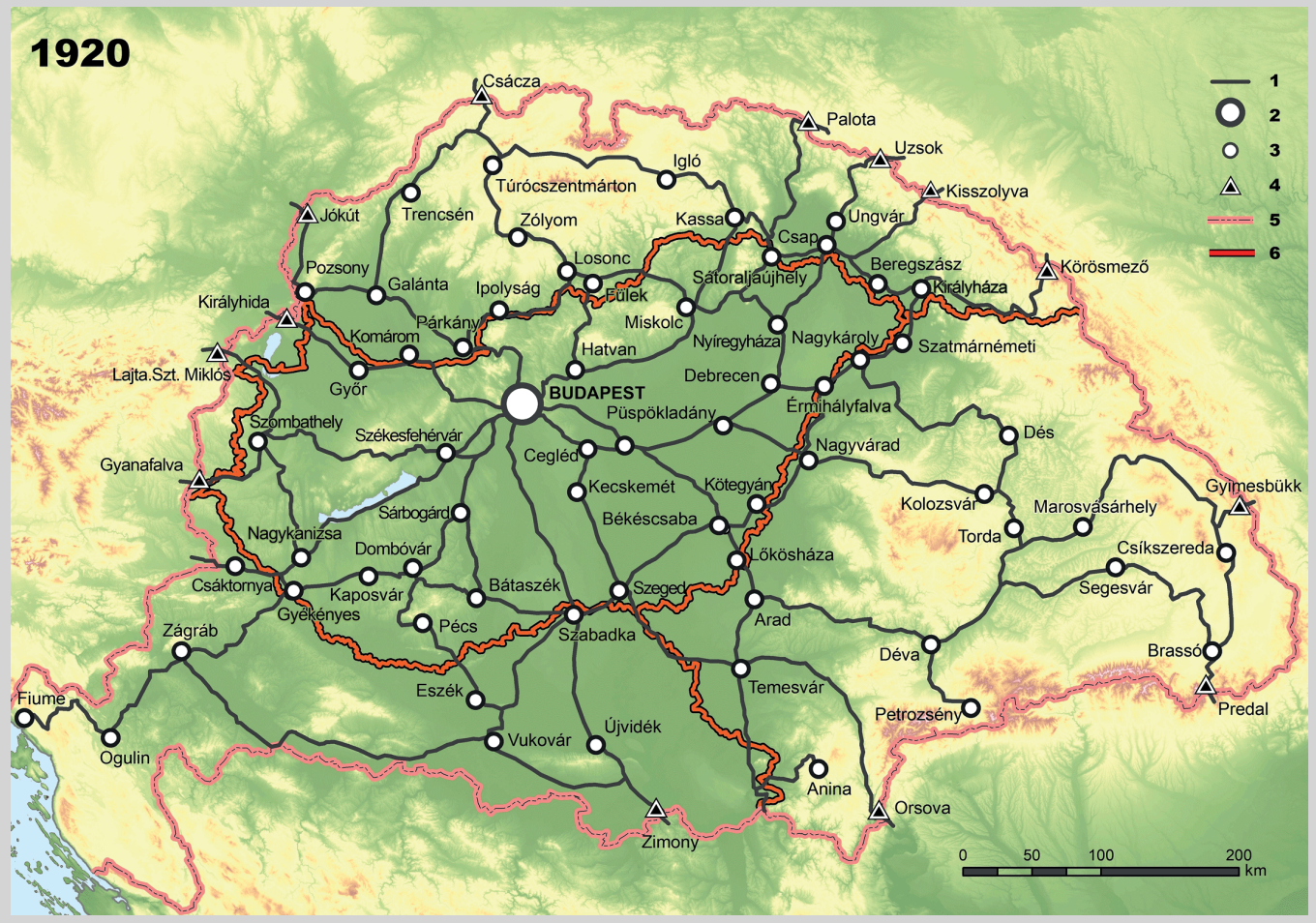

6. ábra. Magyarország szétszakított vasúthálózata 1920-ban (szerk. CsüLLÖG G.). Mint látható, az új határt úgy húzták meg, hogy a Kassa-Csap-Beregszász-Szatmárnémeti-Nagyvárad-Nagyszalonta vasútvonal már az új országok területére essen.

Jelmagyarázat: 1 - fontosabb vasúti fövonal, 2 - székesföváros, 3 - vasúti csomópont, 4 - vasúti határátkelö 1920 elött, 5 - országhatár 1920 elött, 6 - trianoni határ 
szétvágták a birtokát, ebből 597 birtokot a román, 24 birtokot az osztrák, 290 birtokot a cseh és 100 birtokot a jugoszláv határon.

Jó tudni azt is, hogy minden román, csehszlovák, jugoszláv követelés teljesítése esetén Magyarországból nem sok maradt volna, ugyanis ezek az országok legszívesebben felosztották volna egymás között a maradék mai Magyarországot is (7.ábra). Ezt számos olyan fennmaradt korabeli térkép és térképvázlat igazolja, amelyeken a békekonferencia meggyőzésére különböző határvonalakkal összeszabdalták a magyar földet. Végül azonban a békekonferencia meghatározó vezetői nem teljesítették az utódállamok minden követelését, egy bizonyos mértékben gátat szabtak a mohóságuknak.

Sátoraljaújhelynek 1918 előtt két vasútállomása volt: a „nagyállomás” és a „kisállomás”. Az utóbbi, amely a város északi részén feküdt és hivatalosan a SátoraljaújhelyGyártelep nevet viselte, Csehszlovákiához került. A trianoni határmegvonás következtében Sátoraljaújhely vízmüvei csak közös útvonalon lettek megközelíthetők, amely felerészben csehszlovák, felerészben magyar terület volt. Hasonlóan furcsa helyzet alakult ki a román határ menti kötegyáni vasútállomáson, ahol a trianoni határt úgy húzták meg,
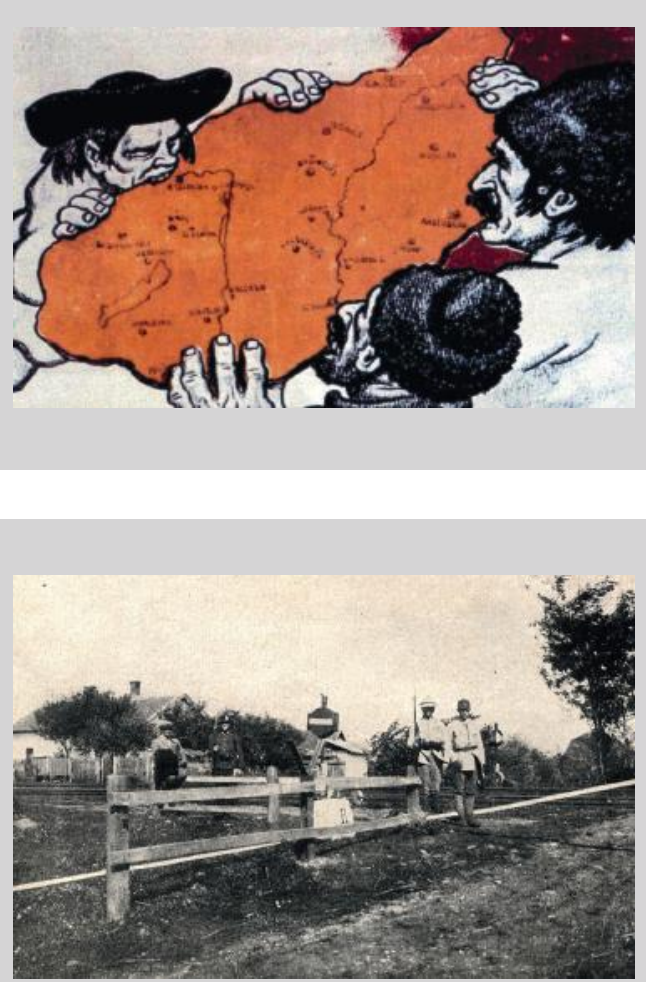
hogy az az állomás vontatási területén megy keresztül (8. ábra); az első váltó már román fennhatóság alá került. Emiatt tolatáskor, vagonrendezéskor a vonatoknak kb. 500-600 méterre át kellett menniük a határon.

$\mathrm{Az}$ osztrák határ mentén Felsőcsatárnál az új határ kitüzésekor kiderült, hogy a határvonal a községtől északnyugatra fekvő cigánykunyhók legészakabbi házát kettészeli, a ház lakószobája osztrák fennhatóság alá került, a konyhája Magyarország része maradt. Ezért a Szombathelyi vámőrkerület

Balra fent: 7. ábra. Korabeli gúnyrajz az utódállamok mohóságáról (forrás: a Magyar Nemzeti Levéltár határmegállapítási anyaga)

Balra: 8. ábra. A kötegyáni vasútállomás fényképe az új határ (a képen fehér vonal jelzi)

meghúzásakor. Mint látható, a váltó már

Románia területére esik (forrás: a Magyar Nemzeti Levéltár határmegállapitási anyaga) 
parancsnoka határmódosításra tett javaslatot, mégpedig hogy a ház vagy Magyarországhoz, vagy Ausztriához tartozzon. Feljegyzésében így érvelt: „...a határvonalnak a házon keresztül való húzódása beláthatatlan következményeket von maga után. Elsősorban a ház lakóinak csempészete kézenfekvő dolog. A csempészárut a ház egyik oldalán beszállítva, a ház másik oldalán már kiszállhatják anélkül, hogy abban határsértés nélkül valaki a lakosokat megakadályozhatná. Ennél súlyosabb esetekről és határincidensekröl is lehet szó..." Végül a kérdést úgy oldódott meg, hogy a magyar kormány kénytelen volt a házat kisajátítani, a módosított új határvonal futása a háznál megtörik és körülöleli az említett házat (SuBA J. 2000b; 9. és 10. ábra).

A határvonal megállapításának egy igazságtalan és a kor jellemzése alapján operettbe illő példája volt a Vas megyei Szentgotthárdi járásban fekvő Felsőszölnök község papi földjének ügye. A Szent Imre plébániához tartozó földeket - amelyek Felsőszölnök, Rábafüzes és Borosgödör (Inzenhof) község határának érintkezési pontja körül terültek el - az új állami határ kettévágta, mert a három község közül Inzenhofot Ausztriának ítélte a békeszerződés. A papi birtok gazdasági épülete mellett volt egy lóvontatású szárazmalom, amit az új határ kettévágott, tehát a

Jobbra fent: 9. ábra. A felsöcsatári cigányviskó, amit eredetileg átszelt a fehér vonallal jelölt határ (forrás: a Magyar Nemzeti Levéltár határmegállapítási anyaga)

Jobbra: 10. ábra. A Felsöcsatár menti határ térképén már látható a viskót körülvevő kiigazított határ (forrás: a Magyar Nemzeti Levéltár határmegállapitási anyaga)
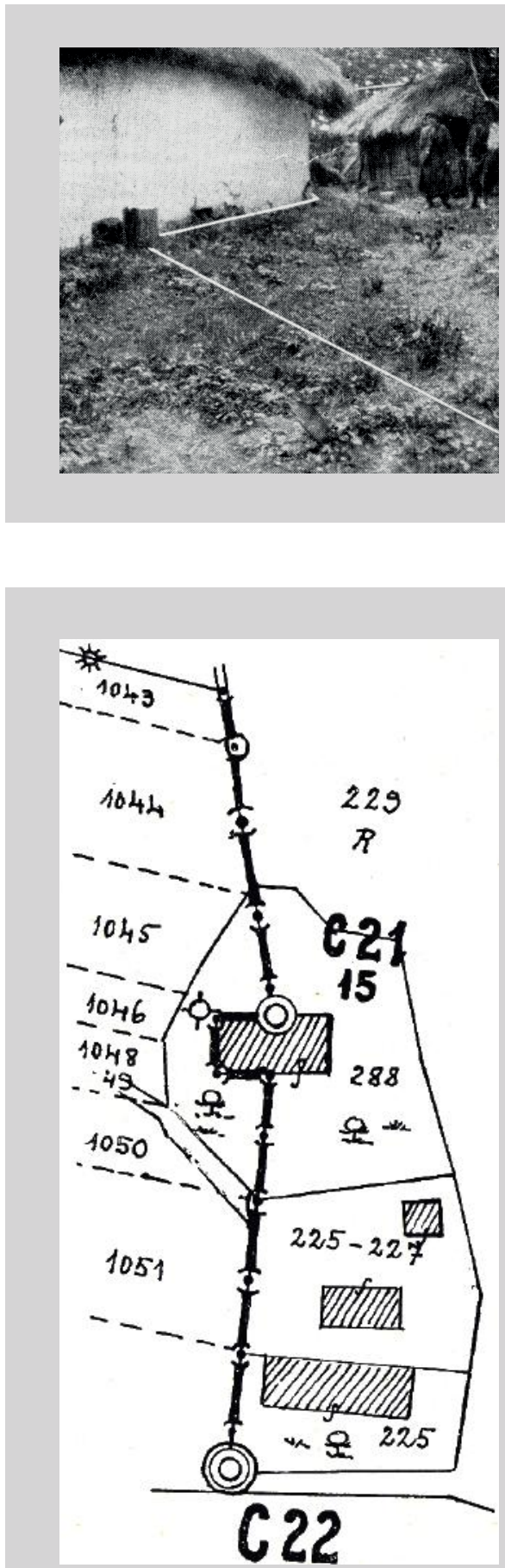
járatási körzetnek (vagyis annak a körnek, amit a ló körben megtesz) egy szakasza átkerült Ausztriához, így őrléskor a járgányt hajtó ló felváltva magyar és osztrák területen járt. Erre a visszás helyzetre a magyar delegáció felhívta az elnök figyelmét a határbejárás során, és végül 1922 végén a határmegállapító bizottság határkiigazítást rendelt el. Természetesen a magyar fél törekvése arra irányult, hogy az összetartozó papi birtokot egészében megmentse, ám erről a pár hektárról az osztrák fél nem volt hajlandó lemondani, így a döntés szigorúan a malom területére vonatkozott és mindössze egy szoba nagyságú, $14 \mathrm{~m}^{2}$-nyi terület átengedését jelentette (Suba J. 2000b).

A nyugati határszélen futó Pinka folyó völgyében a közúti forgalom útvonala egy észak-déli irányú, alig $25 \mathrm{~km}$ hosszú müút. Ez volt a Pinka-völgy egyedüli olyan útja, amely minden évszakban alkalmas volt közlekedésre. A trianoni határ ezt az utat hatszor keresztezi, ami azt jelenti, hogy aki ezt az utat használni akarja, negyedóránként hol magyar, hol osztrák területen jár és tizenkétszeri útlevél- és vámvizsgálaton esik keresztül. A határ itt egyvonalban fekvő közvetlen szomszédos községeket választ el egymástól. A határvonalnak ezen kijelölése mind forgalmi, mind gazdasági szempontokból nagyon nagy hátrányokkal, bajokkal és kellemetlenségekkel járt. Ugyancsak a

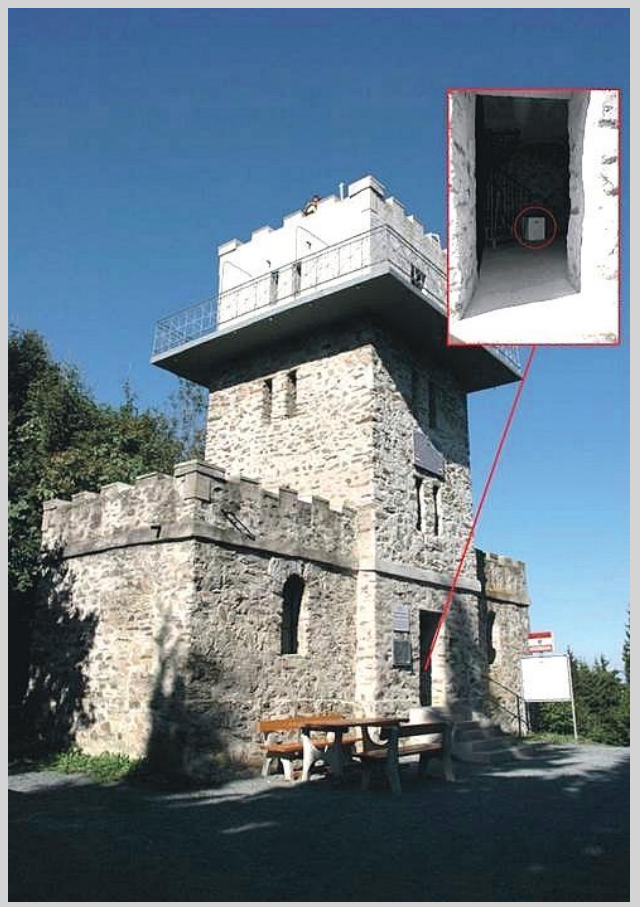
nyugati határszélen a Köszegi-hegység legmagasabb csúcsa, az Írott-kő a békeszerződésben Ausztriához került át. A lábánál fekvő Kőszeg városát turisztikailag ez súlyosan érintette, ugyanis a korábban közeli Rohonc (Rechnitz) település - amelyet a trianoni diktátum Ausztriának ítélt lakossága 1913-ban a csúcson egy 12 méter magas, bástyához hasonlító kő kilátótornyot épített. Magyar kérésre a határmegállapító bizottság helyszíni szemle után kénytelen volt elfogadni a magyar érveléseket, így a határvonalba bekapcsolták a 883 m-es magassági pontot. Mivel e pont fölött van az Árpád-kilátótorony (11. ábra), a bizottság úgy döntött, hogy ennek

11. ábra. Kilátó az Írott-kőn az osztrákmagyar határon és határkö a kilátó belsejében (fotó: Vedó Attila) 
szabad megközelítését mindkét ország részéről lehetővé kell tenni. Az eredeti határkitủzés megváltoztatása révén Magyarország megkapott a kilátótoronyból $21 \mathrm{~m}^{2}$, valamint a Rohonci községi erdőből $140 \mathrm{~m}^{2}$, összesen $161 \mathrm{~m}^{2}$ területet (SUBA J. 2000b).

\section{TOVÁBBI HATÁRKIIGAZÍTÁSOK}

A határmegállapító bizottságok fentebb részletezett tevékenységével elvileg kialakult Magyarország végleges határa, ám az 1920-as évek elején három esetben mégis történt kedvező határmódosítás, amelynek során egy jelentősebb kiterjedésű és két apróbb terület visszakerült Magyarországhoz. Ebből a legnagyobb mérvü, Sopron környéki visszacsatolás története viszonylag jól ismert, ám a másik kettőt ritkán emlegetik.

\section{A soproni népszavazás}

A ma Burgenlandnak nevezett, Magyarországtól Ausztriához csatolt területeket az új osztrák állam csak nehezen tudta birtokba venni, kisebb-nagyobb harci eseményekre is sor került, de végül 1921 novemberében az új magyar állam kiürítette és átadta a területet Ausztriának. Ezt megelőzően 1921 októberében az olaszországi Velencében tárgyalásokra került sor, és az aláírt egyezmény előírta, hogy Sopron városában és egyes környező településeken népszavazás dönthet a terület hovatartozásáról. Az 1921. december 14-16-án megtartott soproni népszavazás során a szavazáson megjelentek 65,1\%-a a magyar államhoz való tartozásra szavazott, így Sopron és környéke, 25682 hektárnyi terület visszakerült (12. ábra). A népszavazást valójában Sopron polgársága döntötte el, ugyanis a város szavazóinak 72,8\%-a szavazott Magyarország mellett, míg a környező nyolc község (Ágfalva, Balf, Fertőboz, Fertőrákos, Harka, Kópháza, Nagycenk és Sopronbánfalva) lakóinak csak 45,5\%-a (CsülLög G. et al. 2020). A döntés nyomán a magyar országgyülés a soproni népszavazás emlékének törvénybe iktatásáról szóló 1922. évi XXIX. törvényben a „Civitas fidelissima”, azaz a „leghüségesebb város” címmel jutalmazta Sopront.

\section{A Szentpéterfa kezdeményezte népszavazás}

A soproni népszavazás után, Burgenland tartomány megszervezésekor Szentpéterfa falu elöljáróinak, Hirschl Ferenc községbírónak és NéMETH János tanítónak a kezdeményezésére tiltakozások kezdődtek az osztrák fennhatóság ellen, amelynek hatására az osztrák kormány népszavazást írt ki. Az 1923. január 10. és március 9. között megrendezett népszavazás eredményeként mind a tíz falu, amely részt vett a véleménynyilvánításban (Alsócsatár, Felsőcsatár, Horvátlövő, Kisnarda, Magyarkeresztes, Nagynarda, 


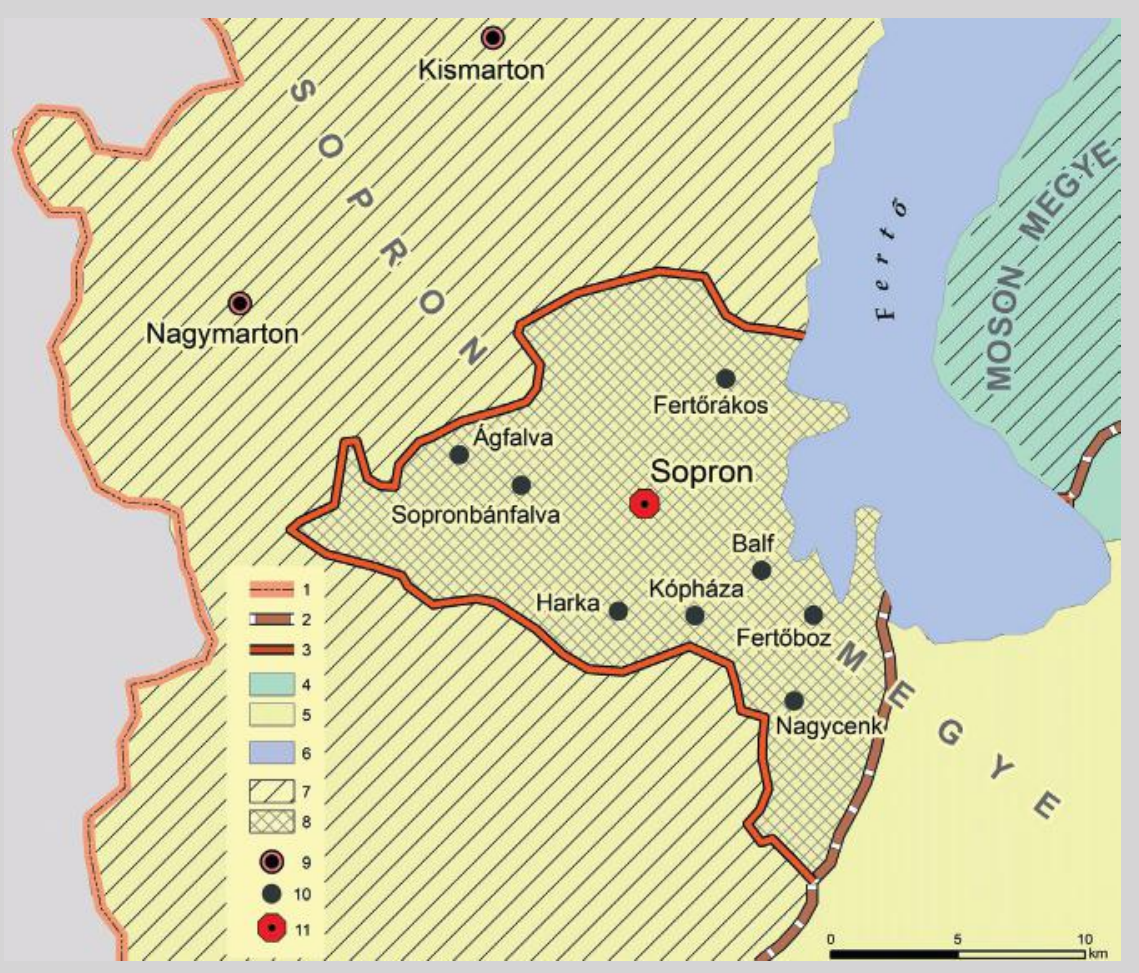

12. ábra. A soproni népszavazás következtében kialakult határmódosítás az új osztrák-magyar határ mentén (szerk. CsüLLÖG G.)

Jelmagyarázat: 1 - Magyarország és Ausztria határa 1920 elött, 2 - Magyarország és Ausztria határa a trianoni szerződés szerint, 3 - határkiigazitás Magyarország javára a soproni népszavazás után, 4 Moson megye területe 1920 elött, 5 - Sopron megye területe 1920 elött, 6 - Ausztria területe 1920 elött, 7 - a trianoni szerzödéssel Ausztriához csatolt magyarországi megyék (a későbbi Burgenland) területe, 8 - a soproni népszavazással visszakerült települések területe, 9 - járásszékhely 1920 előtt, 10 - a soproni népszavazással Sopron mellett visszakerült települések, 11 - megyeszékhely

Németkeresztes, Ólmod. Pornóapáti és Szentpéterfa) a Magyarországhoz történő csatlakozás mellett döntött. A népszavazás eredményét a Nemzetek Szövetsége 1923 márciusában szentesítette. A döntésnek azonban az is része volt, hogy Magyarország viszont négy falut (Karácsfa - Hagensdorf, Lovászad - Luising, Rendek - Liebing és Rőtfalva - Rattersdorf) átadott Ausztriának (SuBA J. 2000b, Csüllög G. et al. 2020; 13. ábra). A visszakerült falvak közül Szentpéterfa 1924-ben megkapta a "Communitas fidelissima”, azaz a „leghüségesebb község” címet, míg a többi települést 2014-ben jutalmazta a magyar országgyűlés a „leghüségesebb falu” címmel. 


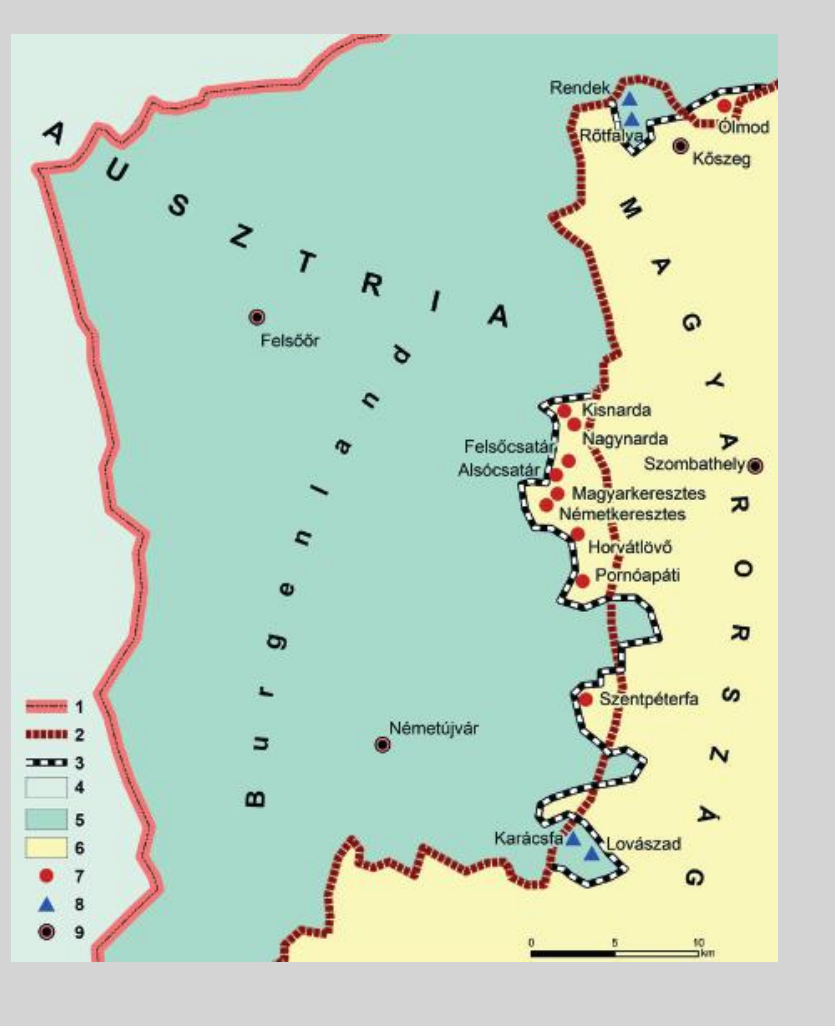

13. ábra. A Szentpéterfa település által kezdeményezett népszavazás következtében kialakult határmódositások az új osztrákmagyar határ mentén (szerk. CsüLLÖG G.)

Jelmagyarázat: 1 - Magyarország és Ausztria határa a trianoni szerzödés elött, 2 - a trianoni szerzödés szerinti határ, $3-a z$ 1923-as módositás után kijelölt határ, 4 - Ausztria területe a trianoni szerzödés elött, 5 - a trianoni szerződésben Ausztriához csatolt magyarországi területek (Burgenland tartomány), 6 Magyarország területe 1923 után, 7 - a határkiigazitással Magyarországhoz visszakerült települések, 8 - a határkiigazitással Ausztriához került települések, 9 egyéb jelentősebb települések

\section{A somoskői határmódosítás}

Mivel a magyar-csehszlovák határmegállapító bizottság ülésein a határ legtöbb szakaszán a trianoni vonalat állapította meg határnak, ezért a magyar törekvések már csak a határvonal helyi jelentőségü kijavítására irányultak. Ilyen volt Salgótarján vidéke, ahol a cél az volt, hogy a környékbeli szén- és kőbányák minél nagyobb része kerüljön vissza. A bizottság 1922. március 22-i ülésén nem született döntés; szavazategyenlőség alakult ki, és az elnök - akinek a szavazata döntött volna - nem mert dönteni, helyette felterjesztette a Nagykövetek Tanácsához, amely visszaküldte a bizottságnak, hogy állapítsa meg a határt a trianoni szerződésnek megfelelően. Mivel az 1922. október 6-i ülésen sem tudtak dönteni, így a kérdést most már Népszövetséghez terjesztették fel (amely illetékes volt). A Népszövetség 1923. április 23-i ülése kompromisszumként egy harmadik megoldást talált, amelynek eredményeképpen Somoskőújfalu és Somoskő községek - és velük együtt a bányajogosítványok területei a bazalt- és szénbányák telepeivel - visszakerültek Magyarországhoz (14. ábra). A kétoldalú tárgyalások során Magyarország engedélyezte 


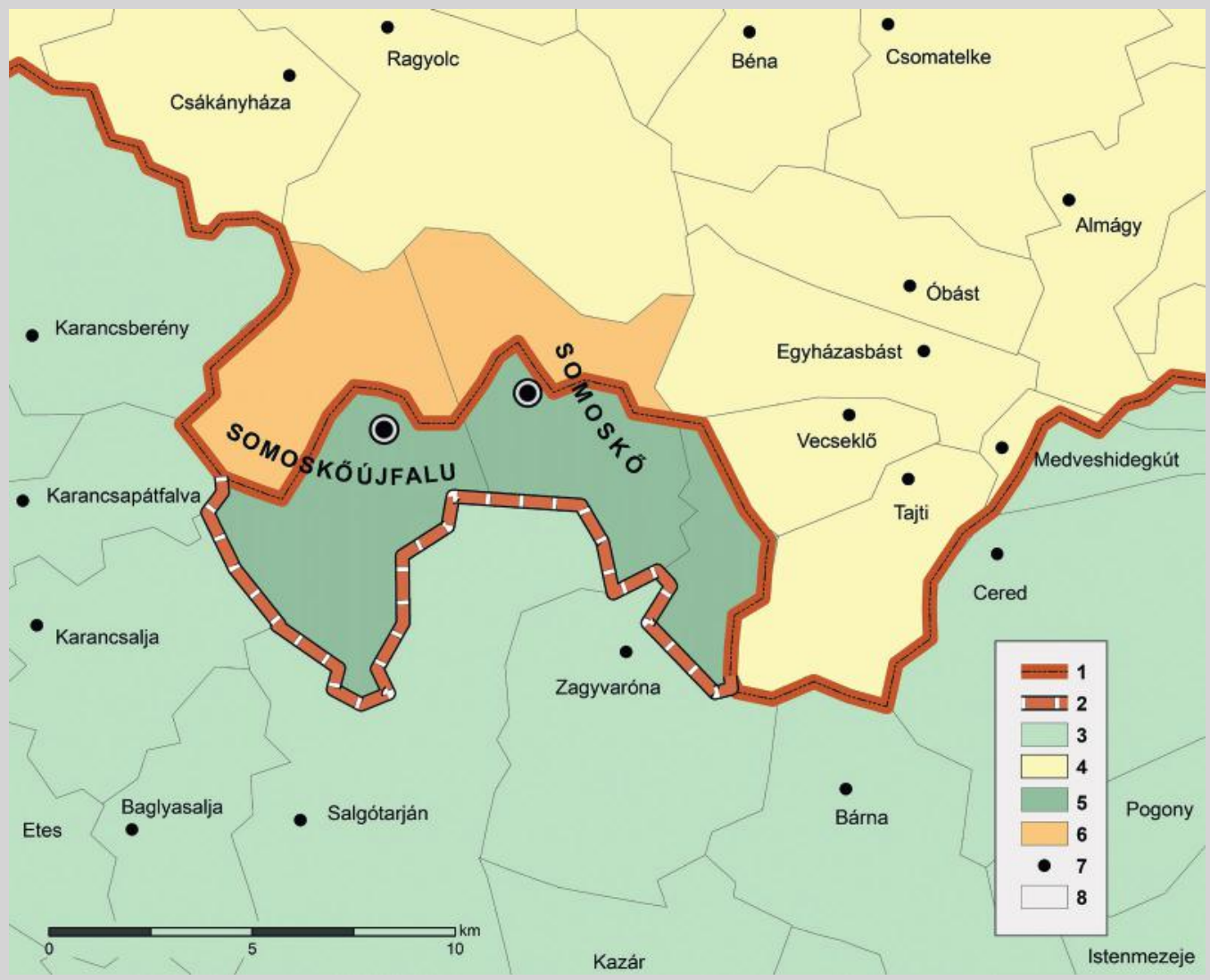

14. ábra. A Somoskö környékén népszövetségi döntés nyomán bekövetkezett határmódositás a csehszlovákmagyar határ mentén (szerk. CsüLLÖG G.)

Jelmagyarázat: 1 - országhatár az 1924. évi határmódositás után, 2 - a trianoni szerzödésben kijelölt országhatár 1920-1924 között, 3 - a Magyarországon maradt települések területe, 4 - a Csehszlovákiához került települések területe, 5 - a Magyarországhoz visszakerült somoskői és somosköújfalui bel-és külterületek, illetve a vecseklői külterület, 6 - a Csehszlovákiánál maradt somosköi és somosköújfalui külterületek, 7 - a települések központjai, 8 - a települések külterületi határai

Csehszlovákiának a somoskőújfalui vasútállomás használatát, míg Csehszlovákia engedélyezte a somoskői Macskalyuki-kőfejtő (Krepuska-féle kőbánya) kitermelését és a termékeknek Magyarországra való szállítását (GALCsıK Zs. 2005, CsüLlöG G. et al. 2020). 1924. február 15-én lezárultak a határviták. Azóta ez a nap a helyiek számára a „hazatérés napja”. Ez a somoskői határrevízió volt az egyetlen olyan változás csehszlovák vonatkozásban a trianoni határokon, amely még napjainkban is érvényes. 


\section{ÖSSZEGZÉS}

Az I. világháborút követően a győztes Szövetséges és Társult Hatalmak a történelmi Magyarországot feldarabolásra ítélték, egykori területének mintegy kétharmad részét más országokhoz, illetve újonnan megszületett államalakulatokhoz csatolták. Mindezt jogi alapra a Magyarország számára kényszerű elfogadásra kötelezett „trianoni” békediktátum helyezte, amelynek természetesen fontos részei voltak az új államalakulatok határainak kijelölésére vonatkozó cikkek. Ezek nyomán határmegállapító bizottságok jöttek létre, amelyek kettős, politikai és müszaki munkájának eredményeképpen alakult ki Magyarország új határa, amelynek hossza az akkori térképek, hivatalos iratok tanulmányozása alapján - kerekítve - 2266 km lett (SubA J. 2016). Ez a határ történelmi mércével mérve fiatalnak tekinthető (még akkor is, ha nem vesszük figyelembe a II. világháború utáni kisebb kiigazítást, újabb három - Pozsony környéki - magyar falu elcsatolását). Visszatekintve megállapítható, hogy a végleges határokat megállapító bizottságok a trianoni békeszerződésben megrajzolt határoktól alapvetően nem tértek el, döntéseikkel az új utódállamok érdekeit szolgálták ki, és a jogos magyar kéréseknek csak igen csekély mértékben tettek eleget. Mindössze három különleges esetben kerülhettek vissza kis területek Magyarországhoz, ebből kettő népszavazással. Elképzelhetjük, mi lett volna, ha minden elcsatolt területen népszavazás lehetett volna...

\section{IRODALOM}

CsÜllög GÁbor - GulYÁs LÁsZló - SubA JÁNos (2020): Térképek a trianoni békediktátum történetéhez. Virtuális Intézet Közép-Európa Kutatására - Magyarságkutató Intézet. Szeged. 318 p.

GALCsıK Zsolt (2005): Nógrád megye közigazgatási és területi változásai (1872-2005). - Nógrád Megyei Levéltár, Salgótarján. 379 p.

KRISZTiCs SÁNDOR (1927): A békeszerződés revíziója. - Grill-féle Könyvkereskedés, Budapest. 508 p.

Suba JÁnos (1997a): A magyar-csehszlovák határ helyszíni megállapítása és kitüzése 1921-1925 között. Limes 10. 28. pp. 29-41.

Suba János (1997b): A magyar-osztrák határ kitűzése és határokmányai. - In: Turbuly É. (szerk.): „Magyarok maradtunk” 1921-1996. Konferencia a Soproni népszavazásról. A Soproni Szemle kiadványai Ujj sorozat 20. Sopron. pp. 71-82.

Suba JÁnos (1999): A Jugoszláv királyság északi határának kitűzése (A Magyar-Jugoszláv Határmegállapító Bizottság müködése 1921-1924). - In: Uhertovich Á. (szerk.): A Jannus Pannonius Múzeum Évkönyve 43. Pécs. pp. 223-242.

Suba János (2000a): A trianoni magyar-román határ kitűzése 1921-1925. - In: Frisnyák S. (szerk.): Pótfüzet Az Alföld történeti földrajza c. konferenciakötethez. Nyíregyháza. pp. 47-55.

Suba JÁnos (2000b): Adalékok a trianoni határ megállapításához Vas vármegyében. - Vasi Szemle 54. 3. pp. 302-309. 
Suba JÁNOs (2002): A politikai földrajz történetileg változó államhatár elmélete. - Geodézia és Kartográfia 54. 6. pp. 14-19.

Suba JÁNos (2004): Az államhatár fogalmának változásai a magyar földrajzi szakirodalomban. - In: Reményi Péter (szerk.): Az Integrálódó Európa politikai földrajza. III. magyar politikai földrajzi konferencia. Pécsi Tudományegyetem Földrajzi Intézet, Pécs. pp. 125-129.

Suba JÁnos (2008): Államhatárok - a földrajzi tér elválasztása. - In: Szabó József - Demeter Gábor (szerk.): Geographia generalis et specialis. Tanulmányok a Kádár László születésének 100. évfordulóján rendezett tudományos konferenciára. Debrecen. pp. 381-386.

Suba János (2016): A Trianoni Magyarország határainak hossza és területe. - Történeti Földrajzi Közlemények 4. 3-4. pp. 150-167.

Tótr József (2011): A határokrul. - In: Frisnyák Sándor - Gál András (szerk.): Kárpát-medence: tájak, népek tevékenységek. - Nyíregyházi Főiskola Turizmus és Földrajztudományi Intézete - Szerencsi Bocskai István Gimnázium, Nyíregyháza-Szerencs. pp. 441-473. 